\title{
Enzymatic Saccharification with Sequential-Substrate Feeding and Sequential-Enzymes Loading to Enhance Fermentable Sugar Production from Sago Hampas
}

\author{
Nurul Haziqah Alias (D), Suraini Abd-Aziz (D), Lai Yee Phang and Mohamad Faizal Ibrahim *(D) \\ Department of Bioprocess Technology, Faculty of Biotechnology and Biomolecular Sciences, \\ Universiti Putra Malaysia, Serdang 43400, Selangor, Malaysia; nhaziqahalias95@gmail.com (N.H.A.); \\ suraini@upm.edu.my (S.A.-A.); phanglaiyee@upm.edu.my (Y.L.P.) \\ * Correspondence: faizal_ibrahim@upm.edu.my; Tel.: +603-9769-1936
}

check for updates

Citation: Alias, N.H.; Abd-Aziz, S.; Phang, L.Y.; Ibrahim, M.F. Enzymatic Saccharification with

Sequential-Substrate Feeding and Sequential-Enzymes Loading to Enhance Fermentable Sugar Production from Sago Hampas. Processes 2021, 9, 535. https:// doi.org/10.3390/pr9030535

Academic Editor: Pietro Bartocci

Received: 31 December 2020

Accepted: 27 January 2021

Published: 18 March 2021

Publisher's Note: MDPI stays neutral with regard to jurisdictional claims in published maps and institutional affiliations.

Copyright: (c) 2021 by the authors. Licensee MDPI, Basel, Switzerland. This article is an open access article distributed under the terms and conditions of the Creative Commons Attribution (CC BY) license (https:// creativecommons.org/licenses/by/ $4.0 /)$.
Abstract: Sago hampas composed of a high percentage of polysaccharides (starch, cellulose and hemicellulose) that make it a suitable substrate for fermentation. However, the saccharification of sago hampas through the batch process is always hampered by its low sugar concentration due to the limitation of the substrate that can be loaded into the system. Increased substrate concentration in the system reduces the ability of enzyme action toward the substrate due to substrate saturation, which increases viscosity and causes inefficient mixing. Therefore, sequential-substrate feeding has been attempted in this study to increase the amount of substrate in the system by feeding the substrate at the selected intervals. At the same time, sequential-enzymes loading has been also evaluated to maximize the amount of enzymes loaded into the system. Results showed that this saccharification with sequential-substrate feeding and sequential-enzymes loading has elevated the solid loading up to $20 \%(w / v)$ and reduced the amount of enzymes used per substrate input by $20 \%$ for amylase and $50 \%$ for cellulase. The strategies implemented have enhanced the fermentable sugar production from $80.33 \mathrm{~g} / \mathrm{L}$ in the batch system to $119.90 \mathrm{~g} / \mathrm{L}$ in this current process. It can be concluded that sequential-substrate feeding and sequential-enzymes loading are capable of increasing the total amount of substrate, the amount of fermentable sugar produced, and at the same time maximize the amount of enzymes used in the system. Hence, it would be a promising solution for both the economic and waste management of the sago hampas industry to produce value-added products via biotechnological means.

Keywords: sago hampas; amylase; cellulase; substrate feeding; saccharification; biomass

\section{Introduction}

Sago palm, scientifically known as Metroxylon sagu, can be found in tropical Southeast Asia. This plant grows healthily in the environment with an average temperature of $25{ }^{\circ} \mathrm{C}$ and an approximate humidity of $70 \%$ [1]. Its ability to thrive in a swampy area and grow naturally without the need for pesticide or herbicide has made sago palm cultivation increase in recent decades [2]. Approximately $90 \%$ of commercially grown sago palm in Malaysia is in Sarawak, a state located in the east of Malaysia. Sago palm became an important economic species and resource for this region as the production of sago starch was reported to be approximately 15-25 tons/ha. The starch composition in sago palm is the highest ( 25 tons $/$ ha) as compared with other types of the plant such as rice (6 tons /ha), corn (5.5 tons/ha), wheat (5 tons/ha) and potato (2.5 tons/ha) [3]. The commercial production of sago starch was established in Malaysia in the 1970s and became one of the most important industries in terms of its contribution to the export revenue [4]. Due to the upward trend in sago starch production, the amount of waste generated from this industry has significantly increased due to the numerous of sago processing mills. The industry of sago palm has generated an extensive amount of waste including sago bark, 
sago hampas and sago wastewater [5]. The polluting effects caused by these agro-wastes have become the main concern and started to generate attention among the researchers attempting to find a solution with a sustainable approach.

In Malaysia, the mass production of sago starch from 600 logs of sago palm per day was 15.6 tons of woody bark, 237.6 tons of wastewater and 7.1 tons of starch fibrous sago pith residue [6]. Starch fibrous sago pith residue or commonly known as sago hampas composed of starchy and lignocellulosic components, which are $54.6 \%$ of starch, $31.7 \%$ of cellulose and hemicellulose, and 3.3\% of lignin [7]. The high polysaccharide content and low lignin composition in sago hampas make this agricultural residue a promising feedstock for fermentation operation. More importantly, there is no pretreatment required before the saccharification process due to the low lignin content in sago hampas [8]. The pretreatment process is one of the crucial and costly processes in the bioconversion of agricultural residue into fermentable sugar before fermentation [9]. This process is important to reduce and/or alter the lignin component, expose the internal structure of cellulose to be accessible by the cellulase [10]. Eliminating this step from the whole process could save huge operational cost. In addition, a high percentage of remaining starch in sago hampas can be easily hydrolysed by amylase to produce fermentable sugar. Therefore, the utilization of sago hampas as a raw material for fermentation operation could be cost-effective for the downstream processing of sugar production and eventually for the production of fermentation-based products, and at the same time, prevent the environmental pollution that is caused by the underutilization of sago waste.

In the production of fermentable sugars from sago hampas, this material must be gelatinized before saccharification. Gelatinization needs to be carried out to break down the hydrogen bond in the sago starch, thus, allowing the amylase to attack the $\alpha$-glycosidic bond of the polysaccharides into glucose monomer [11]. Gelatinization is a simple process that applies the heat to the starch in the presence of water. As a result, the water is gradually absorbed and caused the starch granules to swell [12]. The addition of glucoamylase (EC 3.2.1.3) with a debranching enzyme such as pullulanase (EC 3.2.1.41) is practically useful as they can hydrolyse the $\alpha-1,6$-glycosidic bond that links the polysaccharides chain into branches [13]. The hydrolysis process of starch by amylase takes less than $24 \mathrm{~h} \mathrm{[14]}$ Meanwhile, to fully degrade the sago hampas into fermentable sugar, the cellulase is also being used to degrade the cellulosic component. Cellulase is a mixture of enzymes composed of endoglucanase (EC 3.2.1.4), exoglucanase (EC 3.2.1.91) and $\beta$-glucosidase (EC 3.2.1.21) that act synergistically on the degradation of the $\beta$-glycosidic bond of cellulosic component into glucose monomers [15].

The low sugar concentration always obtained from enzymatic saccharification is usually not enough to initiate the fermentation process. This problem can be overcome by increasing the insoluble solid load that will enhance the fermentable sugar production, and thus, improve the efficiency of the downstream processing. However, increasing the substrate concentration can reduce the hydrolysis yield due to the high viscosity, which subsequently causes poor mixing and mass transfer [16,17]. In addition, the current process also suffers from a high cost of enzymes used in the saccharification process, especially cellulase. Therefore, the improvement of the enzymatic saccharification step is required from an economic perspective and for process feasibility. The mixture of amylase and cellulase used in the saccharification of sago hampas has been previously reported by Husin et al. [7] for the production of biobutanol. It was found that the mixture of amylase and cellulase produced higher fermentable sugar as compared to a single enzyme, either amylase or cellulase alone. However, the process has been done in batch for simultaneous saccharification and fermentation (SSF) to produce biobutanol. Although a high biobutanol production yield was obtained, the low sugar concentration produced by this operation can be improved.

Therefore, in this present study, saccharification with sequential-substrate feeding and sequential-enzymes loading has been introduced with the aim of enhancing the fermentable sugar production, and at the same time, maximize the usage of enzymes in 
the saccharification process. Sequential-substrate feeding is expected to provide sufficient time for enzymes to digest solid material into soluble sugar components, thus improving the capacity of the system to be loaded with a higher amount of substrate. Meanwhile, sequential-enzymes loading is expected to maximize the amount of enzymes used in the system, and technically reduce the cost of enzymes and make the process more feasible.

\section{Materials and Methods}

The experimental design of this study is shown in Figure 1. The sequential-substrate feeding and sequential-enzymes loading were conducted in comparison with the batch process. The process began when the gelatinized, dried and ground sago hampas mixed with acetate buffer were added with the enzymes (amylase and cellulase). Sago hampas in a total of $20 \mathrm{~g} / \mathrm{L}$ was fed sequentially based on the feeding interval followed with the study on the sequential-enzymes loading by loading amylase and cellulase at a different amount. Saccharification was conducted at $60^{\circ} \mathrm{C}, 150 \mathrm{rpm}$ for 6 days or until a stationary production of fermentable sugars was obtained. Then, to optimize the mixing process, the effect of agitation speed was also conducted.

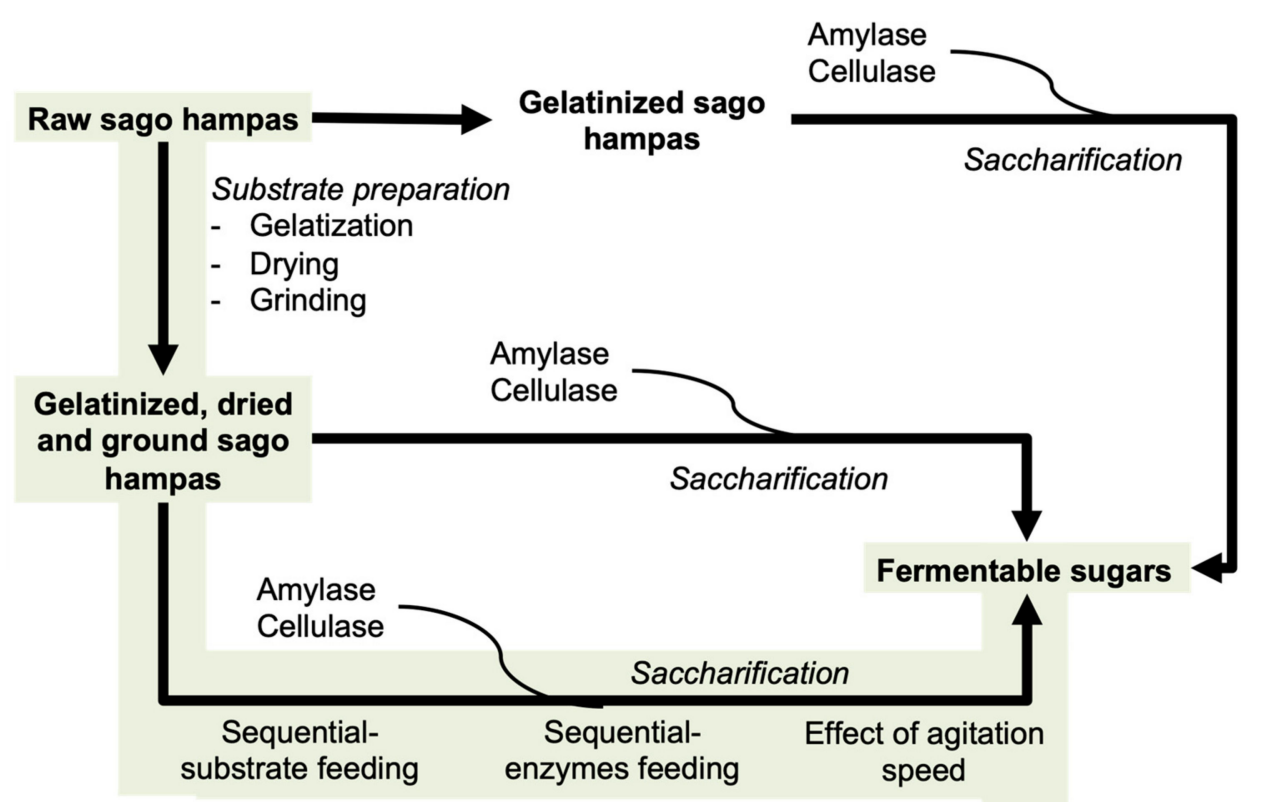

Figure 1. Schematic diagram of experimental work for enzymatic saccharification of sago hampas.

\subsection{Substrate Preparation}

Sago hampas supplied from River Link Sago Resources Sdn. Bhd. in Mukah, Sarawak was sun-dried for 1-2 days to drain off the excess water naturally. Then, sago hampas was gelatinised by boiling in $0.1 \mathrm{M}$ of acetate buffer for $15 \mathrm{~min}$. Then, the gelatinised sago hampas was oven-dried at $60^{\circ} \mathrm{C}$ for $24 \mathrm{~h}$ and subsequently ground to pass a $1 \mathrm{~mm}$ screen. The moisture content of the dried samples was analysed to quantify the buffer to be added prior to the enzymatic saccharification process.

\subsection{Batch Saccharification}

Batch saccharification was conducted following the methods by Husin et al. [7]. An amount of $7 \%(w / v)$ of sago hampas was gelatinized in $100 \mathrm{~mL}$ of $0.1 \mathrm{M}$ acetate buffer solution at $\mathrm{pH} 5.5$ in comparison with $7 \%(w / v)$ of gelatinised, dried and ground sago hampas. The saccharification was conducted by adding Dextrozyme $71.4 \mathrm{U} / \mathrm{g}_{\text {substrate }}$ of amylase (Novozymes, Bagsvaerd, Denmark) and $20 \mathrm{FPU} / \mathrm{g}_{\text {substrate }}$ of Acremonium cellulase (Meiji Seika Co, Japan) into the mixture. The saccharification process was performed at $60{ }^{\circ} \mathrm{C}$ and $150 \mathrm{rpm}$ up to $144 \mathrm{~h}$ of incubation time. All the saccharification process was performed in 
shaker incubator (Labwit, ZHWY-1102C) and samples were drawn out for every $24 \mathrm{~h}$ for the analyses.

\subsection{Sacchatification with Sequential-Substrate Feeding and Sequential-Enzyme Loading}

The strategies applied in this study were developed for optimising the feeding interval of the gelatinised, dried and ground sago hampas as well as the amount of enzymes loading. For this study, two sets of experiment were conducted, which are the enzymes only initially loaded and the enzymes sequentially loaded according to the amount of substrate feeding. Batch saccharification with the total substrate concentration of $20 \%(w / v)$ with $71.4 \mathrm{U} / \mathrm{g}_{\text {substrate }}$ and $20 \mathrm{FPU} / \mathrm{g}_{\text {substrate }}$ of amylase and cellulase, respectively, was performed as a control.

\subsubsection{Feeding Interval}

Table 1 illustrates the strategies behind how the feeding interval was applied. The saccharification process consists of five variables for the feeding interval, which are 0 (control), 6, 12, 24 and $36 \mathrm{~h}$ of interval time. The substrate was fed sequentially based on the feeding interval that makes it the total substrate loading at $20 \%(w / v)$ with the $2 \%$ $(w / v)$ of the initial substrate for each variable except for the control. The substrate was fed only up to $72 \mathrm{~h}$ and prolonged the incubation for another 3 days or until the stationary production of fermentable sugar was obtained. The saccharification was performed with two sets of experiments in order to make the comparison study where the first set was the enzymes that only initially loaded while the second set was the enzymes that were loaded sequentially to per $g$ of substrate feeding.

Table 1. Feeding strategies for the feeding interval of sago hampas on the saccharification process.

\begin{tabular}{cccc}
\hline $\begin{array}{c}\text { Time Interval for } \\
\text { Substrate Feeding (h) }\end{array}$ & Initial Substrate (\%) & $\begin{array}{c}\text { Sequential-Substrate } \\
\text { Feeding (\%) }\end{array}$ & $\begin{array}{c}\text { Total Amount of Substrate } \\
\text { Feeding (\%) }\end{array}$ \\
\hline 0 (control) & 20 & No substrate added & 20 \\
6 & 2 & 1.5 & \\
12 & 2 & 3 & \\
36 & 2 & 9 & \\
\hline
\end{tabular}

\subsubsection{Enzymes Loading}

The effect of enzymes loading were tested on the saccharification with the sequentialsubstrate feeding for both amylase and cellulase, with five variables as illustrated in Table 2. The optimal sequential-substrate feeding was $6 \%(w / v)$ fed sequentially at every $24 \mathrm{~h}$ of interval time. The study was also performed with two sets of experiments: the first set was the initially added enzymes only while the second set was the enzymes added sequentially according to the substrate feeding.

Table 2. Variables for the enzyme loading of amylase and cellulase on the sequential-substrate feeding saccharification.

\begin{tabular}{ccccc}
\hline $\begin{array}{c}\text { Time Interval for } \\
\text { Substrate Feeding and } \\
\text { Enzymes Loading (h) }\end{array}$ & $\begin{array}{c}\text { Sequential-Substrate } \\
\text { Feeding (\%) }\end{array}$ & $\begin{array}{c}\text { Total Substrate } \\
\text { Loading (\%) }\end{array}$ & \multicolumn{2}{c}{ Sequential-Enzymes Loading } \\
\cline { 3 - 4 } & & & Amylase (U/g) & Cellulase (FPU/g) \\
\hline \multirow{2}{*}{24} & \multirow{2}{*}{6} & 20 & 7.1 & 14.3 \\
& & & 14.4 & 15 \\
& & & 285.7 & 20 \\
\hline
\end{tabular}




\subsubsection{Agitation Speed}

The effect of agitation speed was performed after the optimal conditions for sequentialsubstrate feeding and sequential-enzymes loading were obtained. The agitation speeds were set at 60, 90, 120, 150 and $180 \mathrm{rpm}$, and saccharification with no agitation was also conducted as a control.

\subsection{Analytical Procedures}

The starch content was determined using iodine starch colorimetric methods by Nakamura [18]. The lignocellulosic biomass of sago hampas were determined by its three major components which are cellulose, hemicellulose and lignin using the standard procedure of acid hydrolysis method and high performance liquid chromatography (HPLC) from the National Renewable Energy Laboratory method, NREL/TP-510-42623 [19]. Total extractives content were determined following the method by the National Renewable Energy Laboratory method, NREL/TP-510-42619 [20]. The sugar monomers obtained by saccharification were analysed by high performance liquid chromatography (HPLC) (Jasco, Tokyo, Japan) equipped with a refractive index (RI) detector and a column (Shodex KS-801, Tokyo, Japan) for ligand exchange chromatography. A 100\% ultrapure water was used as a mobile phase with a flow rate of $0.6 \mathrm{~mL} / \mathrm{min}$ and the temperature of the column was fixed at $80{ }^{\circ} \mathrm{C}$ using oven column [7]. A statistical analysis was conducted in order to analyse the significant effect from each variable on saccharification process using an analysis of variance (ANOVA) by Statistical Analysis Software (SAS) version 9.4 and verified considering $p<0.05$.

\section{Results and Discussion}

\subsection{Characteristics of Sago Hampas}

The composition of raw sago hampas was determined as shown in Table 3. The characterization of sago hampas in this study has been evaluated in order to ensure the quality of the substrate. All the values shown in the table are comparable to those reported previously. Starch content in sago hampas was $56.0 \%$, while the cellulose, hemicellulose and lignin contents were of $20.7 \%, 11.2 \%$ and $3.1 \%$, respectively. The value of starch content in sago hampas depends on the quality of the extraction process conducted by the sago mills [21]. Besides, both water and solvent extractives in sago hampas have a low value of $2.33 \%$ and $0.67 \%$, respectively.

Starch, cellulose, hemicellulose and lignin are the major components of the sago hampas while extractives are the minor components. Extractives in biomass are usually the non-structural components, which can be extracted by water or other solvents. The solvents can be ethanol, acetone, benzene, hexane, dichloromethane and toluene. The compounds that are commonly extracted out from biomass are fats, waxes, phenolics, resin acids and inorganic compounds. These non-structural components of biomass could potentially interfere with the downstream analysis of the biomass sample. This may result in an error on the structural sugar values where the hydrophobic extractives could inhibit the penetration of the sample that directly caused incomplete hydrolysis [20]. Extractives could also falsely result in high values of lignin when the unhydrolyzed carbohydrates condense with the acid-insoluble lignin. Some studies reported that by removing these extractives, it showed an improvement on the enzymatic digestibility and glucose yield, respectively. Sago hampas has lower total extractives content $(3.0 \%)$ as compared to other types of biomass such as corn stover (13.5\%) and Artemisia ordosica (7.78\%) [22,23]. Therefore, no pretreatment is required to remove the extractive, as this amount is not significantly affecting the saccharification process. Based on this condition of sago hampas (a high carbohydrate composition with low lignin and extractives content), this substrate has a high beneficial advantage to be used as material for the fermentation feedstock. 
Table 3. Comparison of the composition of raw sago hampas with a different collection of sago hampas.

\begin{tabular}{|c|c|c|c|c|c|c|c|c|c|}
\hline \multirow{3}{*}{$\begin{array}{c}\text { Sago } \\
\text { Hampas } \\
\text { Collec- } \\
\text { tion }\end{array}$} & \multicolumn{8}{|c|}{ Composition (\%) } & \multirow{3}{*}{ References } \\
\hline & \multirow{2}{*}{ Starch } & \multirow{2}{*}{ Cellulose } & \multirow{2}{*}{ Hemicellulose } & \multirow{2}{*}{ Lignin } & \multirow{2}{*}{ Moisture } & \multicolumn{2}{|c|}{ Extractives } & \multirow{2}{*}{ Others } & \\
\hline & & & & & & Water & Solvent & & \\
\hline $\begin{array}{c}\text { Pusa, } \\
\text { Sarawak }\end{array}$ & 49.5 & 26.0 & 14.5 & 7.5 & n.d & n.d & n.d & 2.5 & [8] \\
\hline $\begin{array}{c}\text { Pusa, } \\
\text { Sarawak }\end{array}$ & 58.0 & 23.5 & 8.2 & 6.3 & n.d & n.d & n.d & 2.3 & [24] \\
\hline $\begin{array}{l}\text { Mukah, } \\
\text { Sarawak }\end{array}$ & 58.0 & 21.0 & 13.4 & 5.4 & 4.7 & n.d & n.d & 3.13 & [25] \\
\hline $\begin{array}{l}\text { Mukah, } \\
\text { Sarawak }\end{array}$ & 56.0 & 20.7 & 11.2 & 3.1 & 6.35 & 2.33 & 0.67 & 6.1 & $\begin{array}{l}\text { This } \\
\text { study }\end{array}$ \\
\hline
\end{tabular}

n.d indicates not determined.

\subsection{Saccharification of Sago Hampas}

To enhance the fermentable sugar production from sago hampas, several saccharification strategies were carried out by identifying the effects of feeding interval, enzymes loading and agitation speed. The saccharification process was performed by determining the effect of preparing a substrate under wet and dried conditions followed by the sequential feeding of the dried substrate. Then, the effects of initially loaded enzymes and sequentially loaded enzymes throughout the saccharification process were also evaluated. The whole strategies were performed to determine the optimum conditions of the saccharification that can produce the highest fermentable sugar production with a low amount of enzymes loading.

\subsubsection{Effect of Wet and Dried Sago Hampas}

Initially, this particular experiment was carried out to determine the substrate condition used throughout the saccharification process, either in wet or dried condition. This is because in the early study of the saccharification of sago hampas, the sago hampas was gelatinised before the saccharification process, and the gelatinised sago hampas was in the wet condition. However, saccharification of sago hampas with sequential-substrate feeding must be in the dried form to ensure the consistency of the substrate feeding throughout the experiment. The gelatinization process was conducted before the saccharification process due to a high starch content in sago hampas and due to the crystalline structure of the starch. The crystallized structure of starch must be destroyed and change into the amorphous structure in order to make it susceptible to the enzyme action [21]. It works when the substrate suspension is heated in the presence of water and swelling starch granules break down the hydrogen and hydrophobic bonds [24].

In this study, the saccharification profiles of the wet and dried substrates (Figure 2) show that there is no significant difference in the sugar produced from wet and dried substrates, which produced $43.29 \mathrm{~g} / \mathrm{L}( \pm 2.54)$ and $46.23 \mathrm{~g} / \mathrm{L}( \pm 0.76)$ of sugar, respectively. However, it can be seen from the graph that the saccharification rate of the wet substrate is slightly faster as compared to the dried substrate with a slightly lower concentration of sugar being produced. It was suggested that drying the temperature also plays an important role in the characterization of sago starch in terms of drying kinetics and the equilibrium of moisture content [26]. The wet substrate might be easily degraded by amylase since the starch structure has been exposed with water, while dried substrates sometimes need the structure to be accessible by the amylase. 


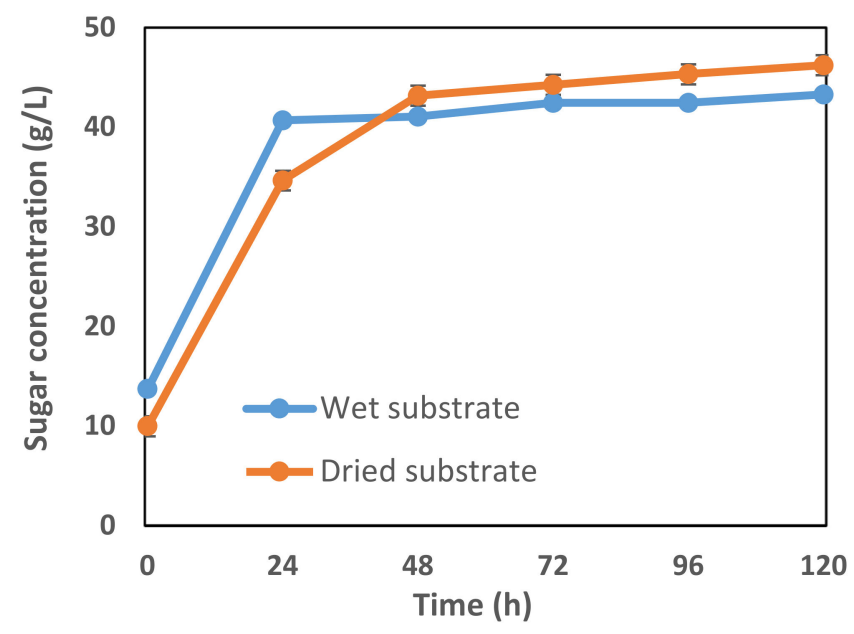

Figure 2. Effects of the wet and dried substrates used in the saccharification process of sago hampas by the mixture of amylase and cellulase.

\subsubsection{Effect of Feeding Interval}

In this study, $20 \%(w / v)$ of the total substrate was saccharified with the added mixture of Dextrozyme amylase $(71.4 \mathrm{U} / \mathrm{g})$ and Acremonium cellulase $(20 \mathrm{FPU} / \mathrm{g})$. However, the high substrate concentration applied in the saccharification process might lead to the high viscosity and subsequently reduced the reaction rate [27]. To saccharify a high amount of substrate, sago hampas must be loaded sequentially throughout the process to maintain the low level of viscosity and increase the accessibility of the enzymes towards the substrate [28]. To examine the effect of feeding interval and the enzymes used, several feeding intervals were conducted in two separate experiments, namely that of the only initially loaded enzymes and enzymes sequentially loaded according to the substrate feeding. All presented data are the means of triplicates \pm S.D and stated using the Tukey's test with $p<0.05$.

Figure 3 a illustrates the effect of the feeding interval of the substrate with the initially loaded enzymes. This experiment was also compared with the control (without substrate feeding), where $20 \%(w / v)$ of the total substrate was added at the beginning of the saccharification. From this study, it can be observed that the control produced more sugars ( $80.33 \mathrm{~g} / \mathrm{L} \pm 0.02)$ as compared with the sequentially added substrate. The sequentially loaded substrate did not show an impressive increment in sugar production, as the enzyme activity might be alleviated throughout the process due to the lower substrate concentration at the beginning [17]. This is because sequential substrate feeding was added with only $2 \%$ $(w / v)$ of substrate loading, whereby, a high amount of enzyme was initially added. Thus, throughout the time, most of the enzyme activity reduced and could not provide sufficient degradation capacity when the substrate was added over time. The extent of the inhibition depends on the ratio of total enzyme to the total substrate. This could be explained by the enzymes' active sites not binding with sufficient substrate at the beginning. Then, the produced sugars might occupy the empty enzyme active site and become an inhibitor to the newly added substrate. In addition, it can be seen that the pattern for the control showed that the saccharification can only be achieved until $48 \mathrm{~h}$ of incubation time. In comparison with the sequential-substrate feeding saccharification, the degree of hydrolysis was observed until $96 \mathrm{~h}$ of incubation time. Even though the sugar production from the control saccharification was higher than that of the sequential-substrate feeding saccharification, the high substrates used became significant waste, as these cannot be further hydrolysed by the enzymes. It seems that the enzyme-substrate complex has reached its maximum saturation point which is most likely due to the jamming effect phenomenon caused by the overcrowding of the substrate, with the enzyme and substrate obstructing one another [29]. 

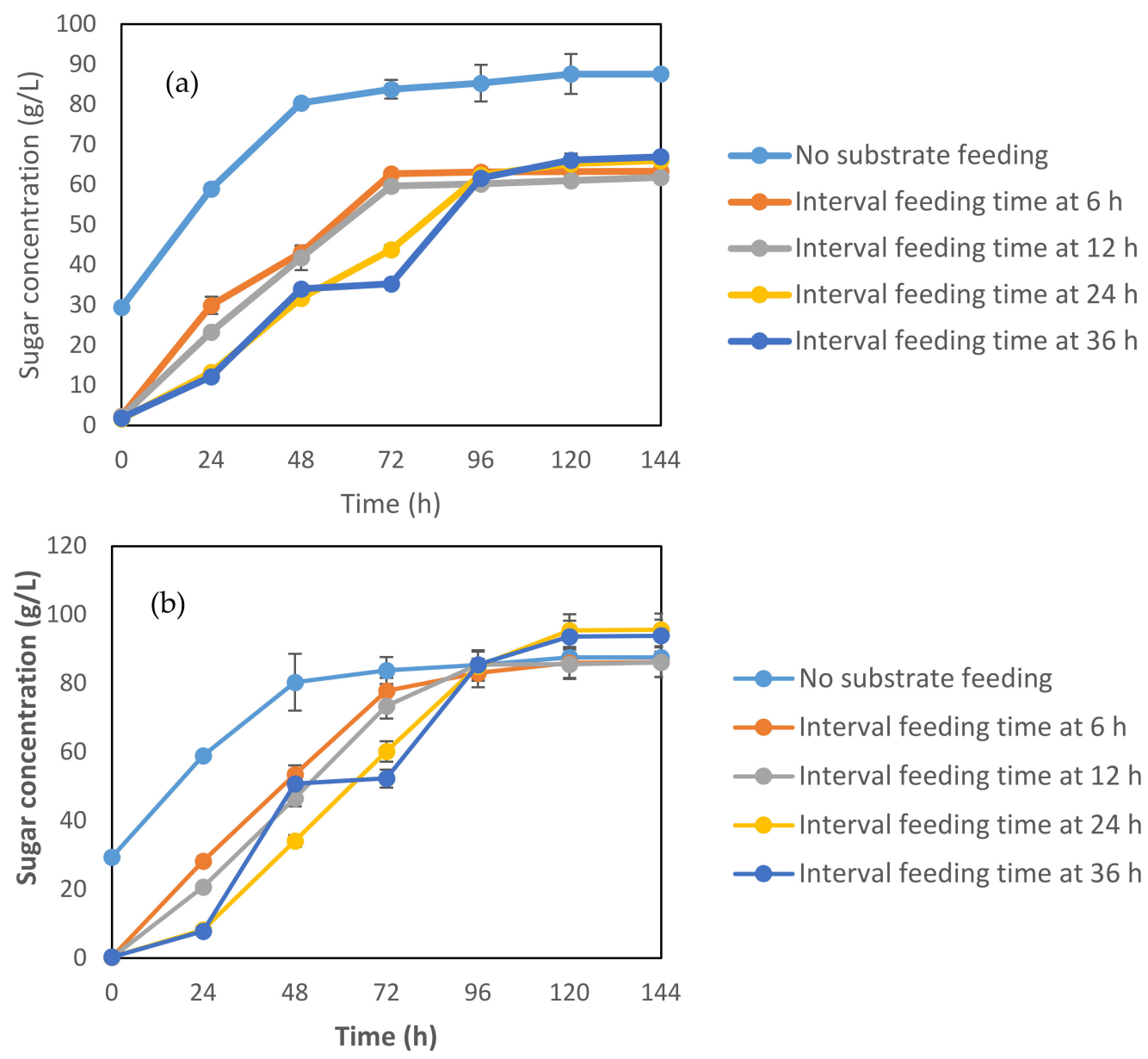

Figure 3. Effect of the feeding interval of the substrate in the saccharification process: (a) initially loaded enzymes only; and (b) sequentially loaded enzymes according to substrate feeding.

Figure $3 \mathrm{~b}$ shows the effect of the feeding interval with sequentially loaded enzymes according to the substrate feeding. From the graph, it can be observed that the effect of feeding interval on saccharification with the sequentially loaded enzymes produced more fermentable sugars as compared with the control. From the graph, the degree of hydrolysis for sequential-substrate feeding saccharification showed that it increases gradually up to $120 \mathrm{~h}$ of incubation time with the addition of substrate compared with the control that reached its maximum saturation point at $48 \mathrm{~h}$ of incubation time. The periodical addition of substrate prolonged the process to produce more fermentable sugars [30]. In the comparison with Figure $3 a$, there is about $34.51 \%$ of increment for sugar production. It can also be observed that the viscosity is reduced and more runny solution can be observed. Thus, a greater fermentable sugars yield was produced. This might be due to the rate of reaction which is affected by the total number of enzymes as well as the concentration of substrate loaded accordingly [31]. The result showed that the rate of saccharification did not decrease with the increase in substrate concentration when the enzyme-to-substrate ratio was kept constant. It can be concluded that the optimal interval feeding time for sequential-substrate feeding with the sequential-enzyme loading was every $24 \mathrm{~h}$, which produced the highest sugar concentration of $(95.37 \mathrm{~g} / \mathrm{L} \pm 0.93)$ with $p<0.05$.

There are several studies reported about the crucial parameters that affect the enzymatic saccharification, and one of the parameters is substrate-related. In this present study, the substrate concentration and feeding style have been discussed in terms of how they affect the saccharification process. The substrate features such as the substrate size, lignin structure and substrate pore surface area also play an important role in the accessibility of the substrate to enzyme [32]. This is because the lignocellulosic biomass has a complex 
structural arrangement, thus, it is more difficult to hydrolyse as compared to starch-based biomass. Most of the lignocellulosic biomass such as corn stover, switch grasses and forest residue need to undergo a pretreatment process prior to saccharification. This is to ensure that the lignin component was removed or reduced and/or altered to allow the interaction of substrate to enzymes.

\subsubsection{Effect of Enzymes Loading}

To establish an economically feasible saccharification process, an appropriate amount of enzyme used must be determined as an enzyme used in sugar production generally contributes a significantly high cost in terms of the total operational cost of converting biomass into value-added products [33]. In the previous experiment, the loaded enzyme was $71.4 \mathrm{U} / \mathrm{g}$ of amylase and $20 \mathrm{FPU} / \mathrm{g}$ of cellulase with the interval feeding time at every $24 \mathrm{~h}$. In this experiment on the effect of enzymes loading, there were five variables for each enzyme range from $7.1 \mathrm{U} / \mathrm{g}$ to $285.7 \mathrm{U} / \mathrm{g}$ for amylase and $5 \mathrm{FPU} / \mathrm{g}$ to $25 \mathrm{FPU} / \mathrm{g}$ of cellulase were examined. All presented data are the means of triplicates \pm S.D and stated using the Tukey's test with $p<0.05$.

Figure $4 \mathrm{a}$ shows the effect of initially loading the enzyme while Figure $4 \mathrm{~b}$ shows the effect of the sequential-enzyme loading on the saccharification with the sequential-substrate feeding. Based on Figure 4a, it can be observed that sugar production declined after $96 \mathrm{~h}$ of incubation time. In addition, when the enzyme was initially loaded, the inhibitors might have formed from the formation of the product, which subsequently caused the competitive inhibition [34] whereby the substrate and inhibitors compete for the same enzyme's active site [35]. Competitive inhibition occurs in one of the enzymes, in this case cellulase since it is considered the principle bottleneck for practical production from lignocellulosic materials. This situation usually occurs with high substrate concentration as the inhibitors limit the enzyme velocity in their biochemical reaction [36]. Thus, high substrate concentration might escalate the possibility of enzyme inhibition caused by product inhibitors. In addition, the availability of the enzyme's active site is limited at high substrate concentration due to the accumulation of excess substrate. Other factors that may contribute to the low degree of polysaccharide conversion at high substrate concentration, mainly because of the decrease within the reactivity of cellulosic material in the course of hydrolysis, different kinds of enzyme inactivation, and the non-specific adsorption of cellulolytic enzymes onto lignin [37]. From this study, the sugar production significantly showed the difference between the various amounts of loaded enzymes.

Meanwhile, based on Figure $4 b$, it showed that the performance of hydrolysis was increased with the sequentially added enzyme, as the ratio of enzyme to the substrate used is one factor that affects the saccharification [38]. When comparing these two studies, the effect of sequential-enzymes loading might reduce the inhibition of the product. In addition, the saccharification process has been prolonged up to $120 \mathrm{~h}$ of incubation time. However, after $120 \mathrm{~h}$ of incubation time, the efficiency of enzyme catalytic reaction has deprived due to the prolonged incubation time, which probably because of the enzyme has achieved its maximum enzyme thermal deactivation process after being exposed at high temperature for a long time [39]. The enzymes' reactivity is mostly associated with the enzyme-related parameters. The maximum utilisation of enzymes during saccharification is important because the enzymes represent the major contribution to the total cost of the bioconversion of biomass to value-added products. The amount of enzyme loading depends on the composition and structural arrangement of the substrate [40]. The effect of sequential-enzyme loading has resulted in approximately a $43 \%$ increment in sugar production as compared with the initially loaded enzymes. This study also showed that sequential-enzyme loading with 10 to $20 \mathrm{FPU} / \mathrm{g}$ cellulase and 14.3 to $142.9 \mathrm{U} / \mathrm{g}$ amylase did not significantly affect sugar production $(p<0.05)$. Hence, the presence of excess enzymes was a waste, since it was usually underutilized and consequently leads to the unnecessarily high cost in the saccharification process. Therefore, a low amount of enzyme 
loading (14.3 U/g of amylase with $10 \mathrm{FPU} / \mathrm{g}$ of cellulase) can be optimally used to produce a high concentration of $(112.48 \mathrm{~g} / \mathrm{L} \pm 1.26)$ with $p<0.05$.
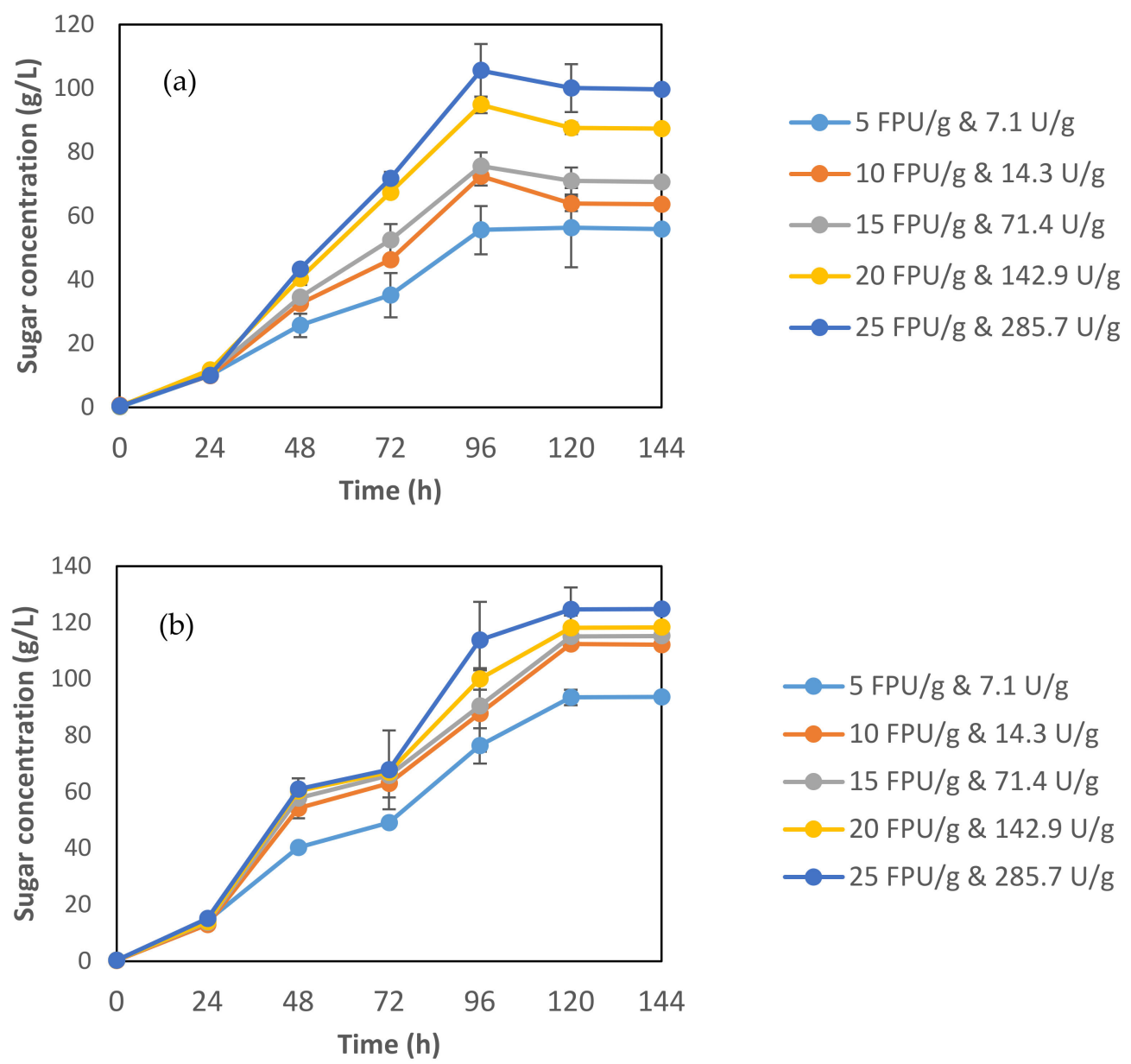

$\longrightarrow 5 \mathrm{FPU} / \mathrm{g} \& 7.1 \mathrm{U} / \mathrm{g}$

$\longrightarrow 10 \mathrm{FPU} / \mathrm{g} \& 14.3 \mathrm{U} / \mathrm{g}$

$\longrightarrow 15 \mathrm{FPU} / \mathrm{g} \& 71.4 \mathrm{U} / \mathrm{g}$

$\longrightarrow 20 \mathrm{FPU} / \mathrm{g} \& 142.9 \mathrm{U} / \mathrm{g}$

$\longrightarrow 25 \mathrm{FPU} / \mathrm{g} \& 285.7 \mathrm{U} / \mathrm{g}$

Figure 4. Effect of loading enzymes on the saccharification process: (a) initially loaded enzymes only; and (b) sequentially loaded enzymes according to substrate feeding.

\subsubsection{Effect of Agitation Speed}

The effect of agitation speed has been evaluated in the range of 60-180 rpm together with no agitation at the constant temperature of $60^{\circ} \mathrm{C}$ for the saccharification of sequentialsubstrate feeding and sequential-enzyme loading. The effect of agitation speed is important to determine the relationship between the saccharification efficiency and liquid viscosity of saccharification. This is because the liquid viscosity from the saccharification process increases with the increase in the saccharification time since the substrate was added sequentially throughout the process.

The trend of fermentable sugar production with different agitation speed for 6 days of incubation is presented in Figure 5 As expected, saccharification with no agitation produced the lowest sugar concentration of $(88.38 \mathrm{~g} / \mathrm{L} \pm 1.52)$. Increasing the agitation speed from 60 to $150 \mathrm{rpm}$ had significantly increased the sugar production to $(119.9 \mathrm{~g} / \mathrm{L} \pm 0.32)$ with $p$-value $<0.5$. Agitation enhances the mass transfer rate during saccharification, thus improving the hydrolysis process and increasing the conversion rate of the substrate into fermentable sugars by the enzymes. It can also be observed that the agitation speed has a moderate effect on saccharification. At a $180 \mathrm{rpm}$ agitation speed, the fermentable sugar production showed a slight reduction probably due to the shear stress or shear forces. It is also reported that vigorous agitation speed could have aggravated cell damage, which in turn led to the mechanical inactivation of the enzymes and contributed to the reduction in enzyme stability. Thus, sugar production was suppressed. In typical saccharification, 
the agitation speed of 120-150 rpm was found to be optimum. Therefore, as for this study, the agitation of $150 \mathrm{rpm}$ can be considered most suitable for the saccharification of sago hampas to produce fermentable sugars. Even though the agitation speed has a moderate effect on saccharification, it still plays an important role in the cost-effective downstream processing as it can reduce energy consumption.

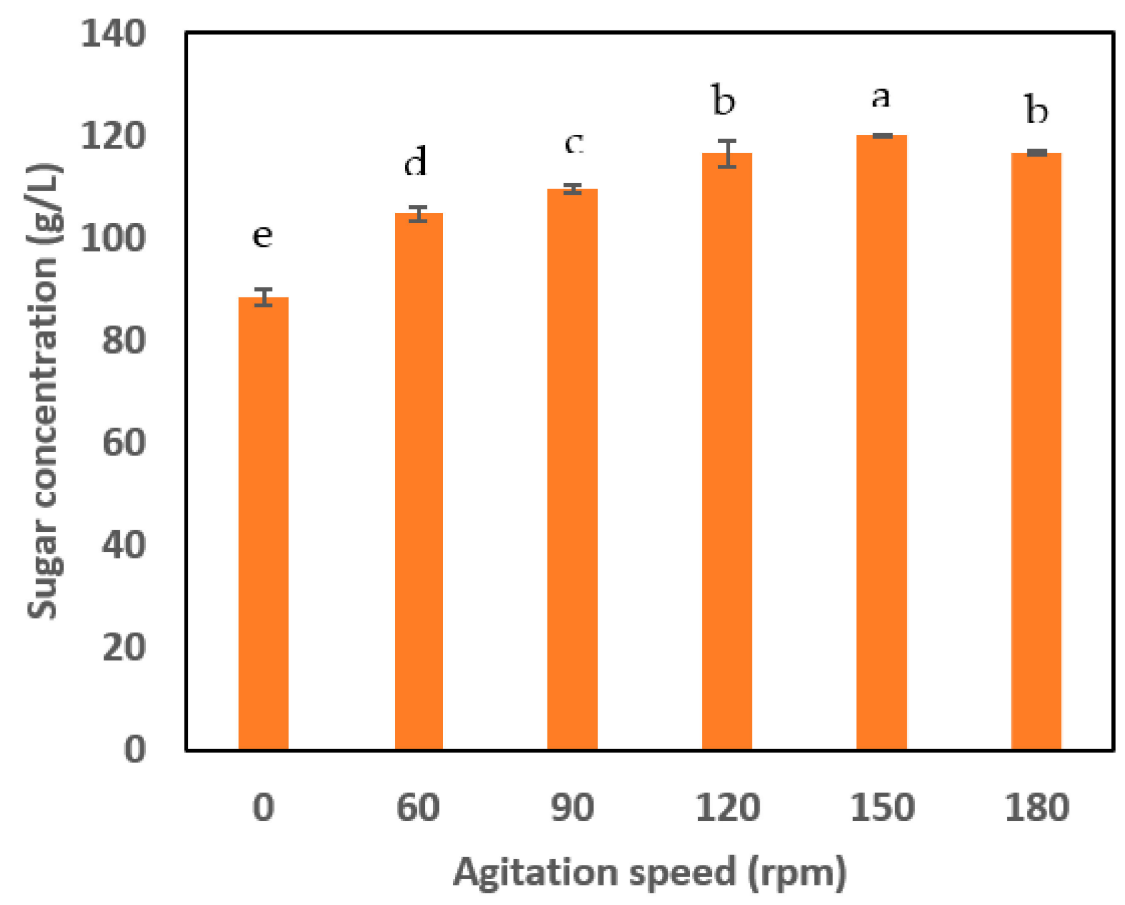

Figure 5. Effect of agitation speed on the saccharification process. All data are the means of 3 replicates \pm S.D. The different alphabet indicates significant difference at $p<0.05$. The data were stated using LSD test.

\subsection{Comparison Study}

This study demonstrated the enhancement of sugar production by conducting saccharification with sequential-substrate feeding and sequential-enzyme loading. The comparison of different saccharification strategies in Table 4 shows that this saccharification strategy significantly improved sugar production compared to other studies. It was $13.53 \%$ of sugar increment which could be observed when comparing the normal saccharification with sequential-substrate feeding. However, throughout the process, the normal saccharification produced more suspended solution because of the high solid-liquid ratio at the beginning of the saccharification. This highly viscous solution was caused by an ineffective heat and mass transfer due to the solution not being mixed properly, and hence, the reduction in the diffusion of the enzyme and end product [27].

In order to further enhance the fermentable sugar production, the rate of saccharification process needs to be increased. However, due to the high prices of commercial cellulase, the addition of more enzymes is not the best option. Alternatively, the rate of saccharification and fermentable sugar production can be accelerated by implementing a new strategy of feeding for both substrate and enzymes. Therefore, the sequential-substrate feeding and sequential-enzymes loading was implemented in this study. Surprisingly, the small difference in the feeding strategies had significantly improved the sugar production by $20.87 \%$ as compared to the process without sequential-enzyme loading. This approach has also reduced the amount of enzyme used for both amylase and cellulase by $20 \%$ and $50 \%$, respectively. 
Table 4. Comparison of sugar production between different strategies of saccharification using sago hampas as a substrate.

\begin{tabular}{|c|c|c|c|c|c|c|}
\hline \multirow[t]{2}{*}{ Study } & \multirow{2}{*}{$\begin{array}{c}\text { Initial } \\
\text { Substrate } \\
\text { Concentration }(\mathrm{g} / \mathrm{L})\end{array}$} & \multirow{2}{*}{$\begin{array}{c}\text { Total } \\
\text { Substrate Loading } \\
(\mathrm{g} / \mathrm{L})\end{array}$} & \multirow{2}{*}{$\begin{array}{l}\text { Feeding Time } \\
\text { Interval } \\
\text { (h) }\end{array}$} & \multicolumn{2}{|c|}{$\begin{array}{l}\text { Enzyme Loading } \\
\text { (per g of the } \\
\text { Substrate) }\end{array}$} & \multirow{2}{*}{$\begin{array}{c}* \text { Sugar } \\
\text { Concentration } \\
(\mathrm{g} / \mathrm{L})\end{array}$} \\
\hline & & & & Amylase (U/g) & Cellulase (U/g) & \\
\hline $\begin{array}{l}\text { Batch saccharification } \\
\text { (wet substrate) }\end{array}$ & 7 & 7 & Null & 71.4 & 20 & $43.29 \pm 2.54$ \\
\hline $\begin{array}{l}\text { Batch saccharification } \\
\text { (dried substrate) }\end{array}$ & 7 & 7 & Null & 71.4 & 20 & $46.23 \pm 0.76$ \\
\hline Batch saccharification (control) & 20 & 20 & Null & 71.4 & 20 & $80.33 \pm 0.02$ \\
\hline $\begin{array}{l}\text { Saccharification with } \\
\text { sequential-substrate feeding } \\
\text { Saccharification with }\end{array}$ & 2 & 20 & Every $24 \mathrm{~h}$ & 71.4 & 20 & $94.88 \pm 2.59$ \\
\hline $\begin{array}{l}\text { sequential-substrate feeding and } \\
\text { sequential-enzymes loading }\end{array}$ & 2 & 20 & Every $24 \mathrm{~h}$ & 14.3 & 10 & $119.90 \pm 0.32$ \\
\hline
\end{tabular}

* All data are the means of 3 replicates \pm S.D. 
The effectiveness of the enzymatic hydrolysis for starch and lignocellulosic components not only depends on the substrate concentration as a whole, but it also requires the optimum synergistic action of the amylase and cellulase components towards the substrate. Sago hampas mainly compose of starch residue (56.0\%) and the starch itself is composed of linear amylose and branched amylopectin. Therefore, glucoamylase (EC 3.2.1.3) with a debranching enzyme, pullulanase (EC 3.2.1.41), was used for this study as it is an exo-acting enzyme that mainly hydrolyses an $\alpha-1,4$ and $\alpha-1,6$ glycosidic bond from the non-reducing ends of starch chains, which leads to the production of glucose. There are some studies which reported that glucoamylase was able to enhance the efficiency of hydrolysis and increase the substrate concentration at the active site of the enzyme catalytic centre by binding to the raw starch granules and disrupt the surface structure of starch [41,42]. Meanwhile, the lignocellulosic components in this study were hydrolysed by cellulase, which is composed of endoglucanase (EC 3.2.1.4), exoglucanase (EC 3.2.1.91) and $\beta$-glucosidase (EC 3.2.1.21) that act synergistically on the degradation of a cellulosic component into glucose monomers. During the saccharification, it is noted that the substrate level should be high enough to provide a sufficient reaction between the enzymes and substrate. Thus, in order to enhance the higher sugar production, it is must proportionally increase the rate of reaction by adding more substrate. However, by relatively adding more substrate, it contributes to the jamming effect due to enzymes needing to act on more portions of the starch and lignocellulosic components [43]. Therefore, the feeding style of substrate and enzymes must be studied in order to achieve the optimal reaction of saccharification. Hence, in this study, the efficiency of saccharification has been improved when the sequential-substrate and enzymes feeding was applied. The enzymes are able to work at their optimal level when they are supplemented according to the amount of fed substrate, instead of being added once at the beginning only.

The correlation between the analysed variables (substrate feeding, enzyme loading and agitation speed) with the sugar production are conducted. From the correlation screening, it can be seen that only enzymes loading was significantly affecting the sugar concentration with $p<0.05$. The strength of enzymes loading and sugar concentration were associated with the $\mathrm{R}^{2}$ value of 0.92 . This is explained that by the increasing enzymes loading, which produces a higher sugar concentration. However, it should be noted that a further increase in enzymes loading is not economically practical. Both the feeding interval and agitation speed resulted in $p>0.05$, where it does not give a significant effect on the sugar concentration. The feeding interval showed an insignificant effect in enhancing the sugar concentration, which might be due to the enzymes that engage with the substrate and were not sufficient when the interval time of the substrate feeding was too long. This will cause the alleviation of enzyme activity and result in the slowing down of the reactions [44]. Agitation speed plays an important role for an effective mixing of the substrate and enzymes. However, by increasing the agitation speed too much, there is no significant effect on the sugar concentration, where the shear forces might occur and lead to cell damage [45]. On top of that, the interaction of enzymes loading towards the feeding interval was conducted and it showed that the coefficient of determination $\left(\mathrm{R}^{2}\right)$ was 0.96 . The $R^{2}$ value indicates that $96 \%$ of the variation in enzyme loading is explained by the feeding interval. Thus, the digestibility of the enzymes toward the substrate was improved as the enzymes were loaded based on the amount of substrate feeding.

In comparison with other studies, as shown in Table 5, a high substrate feeding of $20 \mathrm{~g} / \mathrm{L}$ can be fed in sequential-substrate feeding and fed-batch saccharification as compared to batch saccharification, which is capable of the maximum load substrate feeding at 5-9 g/L. Previous studies have reported the decreased efficiency of hydrolysis when more than $9 \mathrm{~g} / \mathrm{L}$ of solid substrate were used and this was due to product inhibition, enzyme inactivation and the decrease in substrate reactivity [46]. In addition to that, in the fed-batch saccharification [17], a similar situation was observed whereby a high increment in sugar production was obtained as compared to batch saccharification. However, no feeding strategy for enzyme loading was conducted. In comparison with the sequential- 
substrate-feeding and sequential-enzymes loading, fermentable sugar production from sago hampas was significantly improved even at the low amount of loaded enzymes. It shows that sugar production was affected by how the substrate and enzymes were fed. In order to increase sugar production, the rate of reaction needs to be increased by increasing the amount of substrate and enzymes in the system. However, a high solid-liquid ratio could hinder the effective heat and mass transfer and thus limit the diffusion of enzymes and the formation of end products. Therefore, the efficient saccharification process was dependent on the synergistic feeding of the substrate and enzymes.

Table 5. Comparison of sugar production by various substrates, the amount of enzyme used and different saccharification operations.

\begin{tabular}{|c|c|c|c|c|}
\hline Saccharification Operations & $\begin{array}{c}\text { Substrate } \\
\text { Concentration }(g / L)\end{array}$ & $\begin{array}{c}\text { Enzyme Used per } \mathrm{g} \text { of } \\
\text { Substrate }\end{array}$ & $\begin{array}{c}\text { Sugar } \\
\text { Concentration }(g / L)\end{array}$ & References \\
\hline Batch saccharification & $\begin{array}{l}5 \mathrm{~g} / \mathrm{L} \text { oil palm empty } \\
\text { fruit bunch }\end{array}$ & $\begin{array}{l}0.1 \mathrm{~g} / \mathrm{mL} \text { crude } \\
\text { cellulase cocktail }\end{array}$ & $12 \mathrm{~g} / \mathrm{L}$ glucose & [47] \\
\hline Batch saccharification & $\begin{array}{l}5 \mathrm{~g} / \mathrm{L} \text { oil palm empty } \\
\text { fruit bunch }\end{array}$ & $15 \mathrm{FPU} / \mathrm{mL}$ celluclast & $31 \mathrm{~g} / \mathrm{L}$ reducing sugars & [48] \\
\hline Batch saccharification & $\begin{array}{l}9 \mathrm{~g} / \mathrm{L} \text { sago } \\
\text { hampas }\end{array}$ & $\begin{array}{l}71.4 \mathrm{U} / \mathrm{g} \text { Dextrozyme } \\
\text { amylase }+20 \mathrm{FPU} / \mathrm{g} \\
\text { Acremonium cellulase }\end{array}$ & $\begin{array}{l}66.9 \mathrm{~g} / \mathrm{L} \\
\text { reducing sugars }\end{array}$ & [7] \\
\hline Fed-batch saccharification & $\begin{array}{l}20 \mathrm{~g} / \mathrm{L} \text { Jerusalem } \\
\text { artichoke stalks }\end{array}$ & $20 \mathrm{FPU} / \mathrm{g}$ cellulase & $83.7 \mathrm{~g} / \mathrm{L}$ glucose & [17] \\
\hline $\begin{array}{l}\text { Saccharification with } \\
\text { sequential-substrate feeding and } \\
\text { sequential-enzymes loading }\end{array}$ & $\begin{array}{c}20 \mathrm{~g} / \mathrm{L} \text { sago } \\
\text { hampas }\end{array}$ & $\begin{array}{l}14.3 \mathrm{U} / \mathrm{g} \text { Dextrozyme } \\
\text { amylase }+10 \mathrm{FPU} / \mathrm{g} \\
\text { Acremonium cellulase }\end{array}$ & $\begin{array}{c}119.90 \mathrm{~g} / \mathrm{L} \\
\text { glucose } \pm 0.32\end{array}$ & This study \\
\hline
\end{tabular}

The properties of the biomass usually affected by their structure that make the hydrolysis difficult to be carried out with a higher substrate feeding. Some of the biomass with high lignin content usually needs to undergo pretreatment and this increases the total cost of bioconversion. The downstream processing usually occurs with a high cost of production. However, this cost can be reduced by minimizing the enzyme usage and maximizing the amount of substrate used. Enzymatic saccharification with a sequentialsubstrate feeding and sequential-enzymes loading was proven to be a promising strategy for efficient and economical saccharification. This present study is possible to implement on a large-scale processing production. It is suggested to study the proper technology that can be integrated with the present study in order to ensure the feasibility of the process.

\section{Conclusions}

Sago hampas has been notably known as a promising substrate for the production of fermentation-based products due to its high content of polysaccharides and the low lignin composition. In this study, the saccharification of sago hampas into fermentable sugar has been enhanced by implementing the feeding strategies of the substrate and the enzymes together with the effect of agitation speed. It can be concluded that the sequential-substrate feeding at $6 \mathrm{~g} / \mathrm{L}$ for every $24 \mathrm{~h}$ increased the sugar production by $16 \%$ as compared to the batch process. Meanwhile, saccharification with sequential-substrate feeding and sequential-enzymes loading produced a high sugar concentration of $119.90 \mathrm{~g} / \mathrm{L}$, and at the same time reduced the amount of amylase from $71.4 \mathrm{U} / \mathrm{g}_{\text {substrate }}$ to $14.4 \mathrm{U} / \mathrm{g}_{\text {substrate }}$ and cellulase from $20 \mathrm{FPU} / \mathrm{g}_{\text {substrate }}$ to $10 \mathrm{FPU} / \mathrm{g}_{\text {substrate }}$ used in the process. Findings from this research suggest that the potential of sequential-substrate feeding and sequential-enzyme loading can be used as an alternative in improving the saccharification process of other types of substrates in order to obtain a significantly higher amount of fermentable sugar derived from biomass. 
Author Contributions: Conceptualization, M.F.I. and N.H.A.; methodology, M.F.I. and N.H.A.; software, N.H.A.; validation, M.F.I., S.A.-A. and P.L.Y.; formal analysis, N.H.A.; investigation, N.H.A.; resources, N.H.A.; data curation, N.H.A. and M.F.I.; writing—original draft preparation, N.H.A.; writing一review and editing, N.H.A. and M.F.I.; visualization, N.H.A.; supervision, M.F.I., S.A.-A. and P.L.Y.; project administration, M.F.I.; funding acquisition, M.F.I. All authors have read and agreed to the published version of the manuscript.

Funding: This research was financially supported by the Geran Putra, Universiti Putra Malaysia, project number GP/2017/9559300.

Data Availability Statement: All data used to support the funding of this study are included within the article.

Acknowledgments: Highly appreciation to all members of the Environmental Biotechnology Research Group, Universiti Putra Malaysia for their kind support and help.

Conflicts of Interest: The authors declare no conflict of interest.

\section{References}

1. Bujang, K. Potential of sago for commercial production of sugars. In Proceedings of the the 10th International Sago Symposium, Bogor, Indonesia, 29-31 October 2011; pp. 1-7.

2. Pei-Lang, A.T.; Mohamed, A.M.D.; Karim, A.A. Sago starch and composition of associated components in palms of different growth stages. Carbohydr. Polym. 2006, 63, 283-286. [CrossRef]

3. Ishizaki, A. Production, purification, and health benefits of sago sugar. In Proceedings of the Concluding Remarks for the 6th International Sago Symposium; Sago Comm: Riau, Indonesia, 1997; pp. 22-24.

4. Karim, A.A.; Tie, A.P.L.; Manan, D.M.A.; Zaidul, I.S.M. Starch from the sago (Metroxylon sagu) palm tree-Properties, prospects, and challenges as a new industrial source for food and other uses. Compr. Rev. Food Sci. Food Saf. 2008, 7, 215-228. [CrossRef] [PubMed]

5. Awg-Adeni, D.S.; Abd-Aziz, S.; Bujang, K.B.; Hassan, M.A. Bioconversion of Sago Residue into Value Added Products. Afr. J. Biotechnol. 2010, 9, 2016-2021.

6. Ngaini, Z.; Wahi, R.; Halimatulzahara, D.; Mohd Yusoff, N.A.-N. Chemically modified sago waste for oil absorption. Pertanika J. Sci. Technol. 2014, 22, 153-161.

7. Husin, H.; Ibrahim, M.F.; Kamal Bahrin, E.; Abd-Aziz, S. Simultaneous saccharification and fermentation of sago hampas into biobutanol by Clostridium acetobutylicum ATCC 824. Energy Sci. Eng. 2018, 7, 66-75. [CrossRef]

8. Jenol, M.A.; Ibrahim, M.F.; Phang, L.Y.; Salleh, M.M. Sago biomass as a sustainable source for biohydrogen production by Clostridium butyricum A1. BioResources 2014, 9, 1007-1026. [CrossRef]

9. Chaturvedi, V.; Verma, P. An overview of key pretreatment processes employed for bioconversion of lignocellulosic biomass into biofuels and value added products. 3 Biotech 2013, 3, 415-431. [CrossRef] [PubMed]

10. Canilha, L.; Chandel, A.K.; Dos Santos Milessi, S.T.; Antunes, F.A.F.; Da Costa Freitas, L.W.; Das Graças Almeida Felipe, M.; Da Silva, S.S. Bioconversion of sugarcane biomass into ethanol: An overview about composition, pretreatment methods, detoxification of hydrolysates, enzymatic saccharification, and ethanol fermentation. J. Biomed. Biotechnol. 2012, 2012. [CrossRef] [PubMed]

11. Van Der Maarel, M.J.E.C.; Van Der Veen, B.; Uitdehaag, J.C.M.; Leemhuis, H.; Dijkhuizen, L. Properties and applications of starch-converting enzymes of the $\alpha$-amylase family. J. Biotechnol. 2002, 94, 137-155. [CrossRef]

12. Alcázar-Alay, S.C.; Meireles, M.A.A. Physicochemical properties, modifications and applications of starches from different botanical sources. Food Sci. Technol. 2015, 35, 215-236. [CrossRef]

13. Roy, I.; Gupta, M.N. Hydrolysis of starch by a mixture of glucoamylase and pullulanase entrapped individually in calcium alginate beads. Enzyme Microb. Technol. 2004, 34, 26-32. [CrossRef]

14. Goyal, N.; Gupta, J.K.; Soni, S.K. A novel raw starch digesting thermostable $\alpha$-amylase from Bacillus sp. I-3 and its use in the direct hydrolysis of raw potato starch. Enzyme Microb. Technol. 2005, 37, 723-734. [CrossRef]

15. Satari, B.; Karimi, K.; Kumar, R. Cellulose Solvent-Based Pretreatment for Enhanced Second-Generation Biofuel Production: A Review; Royal Society of Chemistry: London, UK, 2019; Volume 3, ISBN 8415683111.

16. Gao, Y.; Xu, J.; Zhang, Y.; Liu, Y.; Liang, C. Optimization of fed-batch enzymatic hydrolysis from alkali-pretreated sugarcane bagasse for high-concentration sugar production. Bioresour. Technol. 2014, 167, 41-45. [CrossRef] [PubMed]

17. Khatun, M.M.; Li, Y.-H.; Liu, C.-G.; Zhao, X.-Q.; Bai, F.-W. Fed-batch Saccharification and ethanol fermentation of Jerusalem Artichoke Stalks by an Inulinase Producing Saccharomyces cerevisiae MK01. R. Soc. Chem. 2015, 5, 107112-107118. [CrossRef]

18. Nakamura, L.K. Lactobacillus amylovorus, a new starch-hydrolyzing species from cattle waste-corn fermentations. Int. J. Syst. Bacteriol. 1981, 31, 56-63. [CrossRef]

19. Sluiter, A.; Hames, B.; Ruiz, R.; Scarlata, C.; Sluiter, J.; Templeton, D. Determination of Sugars, Byproducts, and Degradation Products in Liquid Fraction Process Samples Laboratory Analytical Procedure (LAP); Issue Date: 12/08/2006; Midwest Research Institute: Golden, CO, USA, 2008. 
20. Sluiter, A.; Ruiz, R.; Scarlata, C.; Sluiter, J.; Templeton, D. Determination of Extractives in Biomass: Laboratory Analytical Procedure (LAP); Issue Date 7/17/2005; Midwest Research Institute: Golden, CO, USA, 2008.

21. Awg-Adeni, D.S.; Bujang, K.B.; Hassan, M.A.; Abd-Aziz, S. Recovery of glucose from residual starch of sago hampas for bioethanol production. Biomed Res. Int. 2013, 2013, 935852. [CrossRef]

22. Li, Z.; Yu, Y.; Sun, J.; Li, D.; Huang, Y.; Feng, Y. Effect of extractives on digestibility of cellulose in corn stover with liquid hot water pretreatment. BioResources 2016, 11, 54-70. [CrossRef]

23. Wang, Y.; Wu, L.; Wang, C.; Yu, J.; Yang, Z. Investigating the influence of extractives on the oil yield and alkane production obtained from three kinds of biomass via deoxy-liquefaction. Bioresour. Technol. 2011, 102, 7190-7195. [CrossRef]

24. Vincent, M.; Jabang, E.; Nur, N.M.; Esut, E.; Unting, L.B.; Awg-Adeni, D.S. Simultaneous co-Saccharification and Fermentation of Sago Hampas for Bioethanol Production. Agric. Eng. Int. CIGR J. 2015, 17, 160-167.

25. Jenol, M.A.; Ibrahim, M.F.; Bahrin, E.K.; Kim, S.W.; Abd-Aziz, S. Direct bioelectricity generation from sago hampas by clostridium beijerinckii sr1 using microbial fuel cell. Molecules 2019, 24, 2397. [CrossRef]

26. Mustafa Kamal, M.; Baini, R.; Mohamaddan, S.; Selaman, O.S.; Ahmad Zauzi, N.; Rahman, M.R.; Abdul Rahman, N.; Chong, K.H.; Atan, M.F.; Abdul Samat, N.A.S.; et al. Effect of temperature to the properties of sago starch. IOP Conf. Ser. Mater. Sci. Eng. 2017, 206. [CrossRef]

27. Yan, S.; Yao, J.; Yao, L.; Zhi, Z.; Chen, X.; Wu, J. Fed batch enzymatic saccharification of food waste improves the sugar concentration in the hydrolysates and eventually the ethanol fermentation by saccharomyces cerevisiae H058. Braz. Arch. Biol. Technol. 2012, 55, 183-192. [CrossRef]

28. Kumar, L.; Arantes, V.; Chandra, R.; Saddler, J. The lignin present in steam pretreated softwood binds enzymes and limits cellulose accessibility. Bioresour. Technol. 2012, 103, 201-208. [CrossRef] [PubMed]

29. Bommarius, A.S.; Katona, A.; Cheben, S.E.; Patel, A.S.; Ragauskas, A.J.; Knudson, K.; Pu, Y. Cellulase kinetics as a function of cellulose pretreatment. Metab. Eng. 2008, 10,370-381. [CrossRef]

30. Lu, C.; Dong, J.; Yang, S.-T. Butanol production from wood pulping hydrolysate in an integrated fermentation-gas stripping process. Bioresour. Technol. 2013, 143, 467-475. [CrossRef] [PubMed]

31. Van Dyk, J.S.; Pletschke, B.I. A review of lignocellulose bioconversion using enzymatic hydrolysis and synergistic cooperation between enzymes-Factors affecting enzymes, conversion and synergy. Biotechnol. Adv. 2012, 30, 1458-1480. [CrossRef] [PubMed]

32. Leu, S.Y.; Zhu, J.Y. Substrate-Related Factors Affecting Enzymatic Saccharification of Lignocelluloses: Our Recent Understanding. Bioenergy Res. 2013, 6, 405-415. [CrossRef]

33. Mathew, G.M.; Sukumaran, R.K.; Singhania, R.R.; Pandey, A. Progress in research on fungal cellulases for lignocellulose degradation. J. Sci. Ind. Res. 2008, 67, 898-907.

34. Kim, D. Physico-chemical conversion of lignocellulose: Inhibitor effects and detoxification strategies: A mini review. Molecules 2018, 23, 309. [CrossRef]

35. Yoon, J.-J.; Kim, K.-Y.; Cha, C.-J. Purification and characterization of thermostable $\beta$-glucosidase from the brown-rot basidiomycete Fomitopsis palustris grown on microcrystalline cellulose. J. Microbiol. 2008, 46, 51-55. [CrossRef] [PubMed]

36. Ojeda, K.; Kafarov, V. Exergy analysis of enzymatic hydrolysis reactors for transformation of lignocellulosic biomass to bioethanol. Chem. Eng. J. 2009, 154, 390-395. [CrossRef]

37. Mussatto, S.I.; Dragone, G.; Fernandes, M.; Milagres, A.M.F.; Roberto, I.C. The effect of agitation speed, enzyme loading and substrate concentration on enzymatic hydrolysis of cellulose from brewer's spent grain. Cellulose 2008, 15, 711. [CrossRef]

38. Hu, J.; Arantes, V.; Saddler, J.N. The enhancement of enzymatic hydrolysis of lignocellulosic substrates by the addition of accessory enzymes such as xylanase: Is it an additive or synergistic effect? Biotechnol. Biofuels 2011, 4, 1-13. [CrossRef] [PubMed]

39. Hawker, J.; Jenner, C. High temperature affects the activity of enzymes in the committed pathway of starch synthesis in developing wheat endosperm. Aust. J. Plant Physiol. 1993, 20, 197-209. [CrossRef]

40. Amit, K.; Nakachew, M.; Yilkal, B.; Mukesh, Y. A review of factors affecting enzymatic hydrolysis of pretreated lignocellulosic Biomass. Res. J. Chem. Environ. 2018, 22, 62-67.

41. Sorimachi, K.; Le Gal-Coëffet, M.F.; Williamson, G.; Archer, D.B.; Williamson, M.P. Solution structure of the granular starch binding domain of Aspergillus niger glucoamylase bound to $\beta$-cyclodextrin. Structure 1997, 5, 647-661. [CrossRef]

42. Xu, Q.S.; Yan, Y.S.; Feng, J.X. Efficient hydrolysis of raw starch and ethanol fermentation: A novel raw starch-digesting glucoamylase from Penicillium oxalicum. Biotechnol. Biofuels 2016, 9, 1-18. [CrossRef] [PubMed]

43. Eveleigh, D.; Mandels, M.; Andreotti, R.; Roche, C. Measurement of saccharifying cellulase. Biotechnol. Biofuels 2009, 2, 1-8. [CrossRef] [PubMed]

44. Robinson, P.K. Enzymes: Principles and biotechnological applications. Essays Biochem. 2015, 59, 1-41. [CrossRef]

45. Liu, Z.; Smith, S.R. Enzyme Recovery from Biological Wastewater Treatment. Waste Biomass Valorization 2020. [CrossRef]

46. Chen, M.; Zhao, J.; Xia, L. Enzymatic hydrolysis of maize straw polysaccharides for the production of reducing sugars. Carbohydr. Polym. 2008, 71, 411-415. [CrossRef]

47. Ibrahim, M.F.; Linggang, S.; Jenol, M.A.; Yee, P.L.; Abd-Aziz, S. Effect of Buffering System on Acetone-Butanol-Ethanol Fermentation by Clostridium acetobutylicum ATCC 824 using Pretreated Oil Palm Empty Fruit Bunch. BioResources 2015, 10, $3890-3907$. [CrossRef]

48. Salleh, M.S.M.; Ibrahim, M.F.; Roslan, A.M.; Abd-Aziz, S. Improved Biobutanol Production in 2-L Simultaneous Saccharification and Fermentation with Delayed Yeast Extract Feeding and in-situ Recovery. Sci. Rep. 2019, 9, 1-9. [CrossRef] [PubMed] 